\title{
Clinical potential of lixisenatide once daily treatment for type 2 diabetes mellitus
}

This article was published in the following Dove Press journal:

Diabetes, Metabolic Syndrome and Obesity:Targets and Therapy 14 June 2013

Number of times this article has been viewed

\author{
Andreas B Petersen' \\ Mikkel Christensen ${ }^{1,2}$ \\ 'Department of Clinical \\ Pharmacology, Bispebjerg Hospital, \\ Copenhagen, Denmark; ${ }^{2}$ Diabetes \\ Research Division, Department of \\ Internal Medicine, Gentofte Hospital, \\ Copenhagen, Denmark
}

\begin{abstract}
The glucagon-like peptide (GLP)-1 receptor agonist lixisenatide (Lyxumia ${ }^{\circledR}$ ) was approved for marketing by the European Medicines Agency in February 2013 and has been evaluated in a clinical study program called GetGoal. Lixisenatide activates the GLP-1 receptor and thereby exercises the range of physiological effects generated by GLP-1, which consist of increased insulin secretion, inhibition of glucagon secretion, and decreased gastrointestinal motility alongside the promotion of satiety. In the GetGoal study program, lixisenatide demonstrated significant reductions in glycated hemoglobin $\left(\mathrm{HbA}_{1 \mathrm{c}}\right)$, and fasting and postprandial plasma glucose compared with placebo. The effect on glycemia was evident, with both monotherapy and in combination with insulin and various oral antidiabetic agents. Furthermore, a general trend towards reduced bodyweight was reported. In head-to-head trials with the other GLP-1 receptor agonists (exenatide and liraglutide) on the market, lixisenatide demonstrated a superior effect with respect to reduction in postprandial plasma glucose and had a tendency towards fewer adverse events. However, lixisenatide seemed to be less efficient or at best, equivalent to exenatide and liraglutide in reducing $\mathrm{HbA}_{1 \mathrm{c}}$, fasting plasma glucose, and bodyweight. The combination of a substantial effect on postprandial plasma glucose and a labeling with once daily administration separates lixisenatide from the other GLP-1 receptor agonists. The combination of basal insulin, having a lowering effect on fasting plasma glucose, and lixisenatide, curtailing the postprandial glucose excursions, makes sense from a clinical point of view. Not surprisingly, lixisenatide is undergoing clinical development as a combination product with insulin glargine $\left(\right.$ Lantus $\left.^{\circledR}\right)$. At present the main place in therapy of lixisenatide seems to be in combination with basal insulin. A large multicenter study will determine the future potential of lixisenatide in preventing cardiovascular events and mortality, in patients with type 2 diabetes and recent acute coronary syndrome.
\end{abstract}

Keywords: GLP-1, incretin, pharmacology, GetGoal, T2DM

\section{Pathophysiology of type 2 diabetes mellitus (T2DM) and glycemic control}

$\mathrm{T} 2 \mathrm{DM}$ is a result of both heritage and environment. The fast-increasing prevalence of T2DM during recent years is, however, mainly seen as a consequence of an evolution towards a sedentary lifestyle and overeating. It is estimated that in 2025, almost 400 million people worldwide will suffer from diabetes, with T2DM comprising more than $90 \%$ of the cases. ${ }^{1}$ T2DM is a multifaceted disease characterized by a disruption of glucose and lipid metabolism, leading to hyperglycemia in both the fasting and postprandial state. It has been suggested that postprandial glycemic excursions play a major role in the metabolic disequilibrium of patients suffering from mild 
or moderate hyperglycemia, whereas the role decreases as patients progress toward poorer diabetic control ${ }^{2}$ - fasting hyperglycemia appears to be a main contributor to the overall hyperglycemia in poorly controlled diabetic patients. ${ }^{2}$

Subjects with T2DM exhibit peripheral and hepatic insulin resistance, $\beta$-cell dysfunction (including an absent early insulin secretory response), reduced $\beta$-cell mass, and glucagon hypersecretion. ${ }^{3}$ The compromized $\beta$-cell function seems to be partly due to an impaired response to the incretin hormones glucagon-like peptide-1 (GLP-1) and glucose-dependent insulinotropic polypeptide (GIP). ${ }^{4}$ T2DM is typically a progressive disease characterized by worsening glycemia, which over time necessitates escalating pharmacotherapy if treatment goals are to be met. ${ }^{5}$

Patients with T2DM have a reduced life span expectancy of up to 10 years, primarily due to an increased risk of fatal cardiovascular events. ${ }^{6}$ In order to reduce this risk, it is very important to treat cardiovascular risk factors, such as obesity, hyperlipidemia, and hypertension. ${ }^{7}$ In addition, it is well established that the risk of microvascular and macrovascular complications is related to overall glycemia, as measured by glycated hemoglobin $\left(\mathrm{HbA}_{1 \mathrm{c}}\right)$, and this remains a major focus of therapy. ${ }^{8}$

A variety of therapeutic options are available for the treatment of hyperglycemia in patients with T2DM. It is generally accepted that the initial therapy should consist of lifestyle changes plus metformin. ${ }^{8}$ The American Diabetes Association and the European Association for the Study of Diabetes recommends lowering $\mathrm{HbA}_{1 \mathrm{c}}$ to $<7.0 \%$ in most patients. Furthermore, fasting and premeal glucose should be maintained at $<7.2 \mathrm{mmol} / \mathrm{L}$ and the postprandial glucose (PPG) at $<10 \mathrm{mmol} / \mathrm{L}^{8}$ These recommendations should be considered within the context of the needs, preferences, and tolerances of each patient. If needed, several different drugs (sulfonylureas, insulin, dipeptidyl peptidase [DPP]-4 inhibitors, and GLP-1 receptor agonists) can be used in combination with metformin to reach an individualized $\mathrm{HbA}_{1 \mathrm{c}}$ target. A general lack of comparative effectiveness research regarding these different antidiabetic drugs makes it difficult to put together a preferred algorithm when considering add-on treatment to metformin. ${ }^{8}$ All of these agents, used alone or in combination, are associated with different adverse events (eg, hypoglycemia, weight gain, and/or gastrointestinal side effects) that must be taken into account.

Three GLP-1 receptor agonists (GLP-1RAs), exenatide twice daily (Byetta ${ }^{\circledR}$; Amylin Pharmaceuticals, Inc, San Diego, CA, USA), exenatide once weekly (Bydureon ${ }^{\circledR}$; Bristol-Myers Squibb, New York, NY, USA and AstraZeneca,
London, UK), and liraglutide once daily (Victoza ${ }^{\circledR}$; Novo Nordisk, Bagsværd, Copenhagen, Denmark) are currently available for the treatment of T2DM. In November 2012, the European Medicines Agency adopted a positive opinion for the new GLP-1RA, lixisenatide (Lyxumia ${ }^{\circledR}$; Sanofi SA, Paris, France), and this was followed by marketing approval in February 2013.

The aim of this manuscript was to review the clinical data of lixisenatide, identified by searching the US National Institutes of Health registry (ClinicalTrials.gov), and reviewing Medline indexed published articles and scientific meeting posters and abstracts.

\section{The incretin system as a therapeutic target for T2DM}

The incretin effect refers to the amplification of insulin secretion elicited by hormones secreted from the gastrointestinal tract. ${ }^{9}$ The effect is quantified by comparing insulin responses to oral and intravenous glucose administration, in amounts adjusted in order to achieve identical glucose excursions. ${ }^{10}$ The incretin effect has been shown to account for as much as $50 \%-70 \%$ of insulin secretion following oral glucose ingestion in healthy subjects. ${ }^{11}$ The incretin effect is markedly reduced in patients with T2DM, and this contributes importantly to the postprandial hyperglycemia seen in these patients. ${ }^{12}$ In addition to the insulinotropic effect, the incretin hormones have a variety of advantageous effects in relation to the typical phenotype of patients with T2DM, as will be addressed below.

Currently, it is generally agreed upon that the incretin effect is mainly constituted by the two incretin hormones GLP-1 and GIP. ${ }^{13}$ The effects of the two hormones, with respect to insulin secretion, is additive, and they seem to make an equal contribution to the incretin effect in healthy subjects. ${ }^{14}$ However, in a study by Nauck et al, ${ }^{15}$ GIP was reported to make a larger contribution to the incretin effect than GLP-1. The insulinotropic effect of GIP is severely impaired in most patients with T2DM, whereas the effect of GLP-1 is retained at supraphysiological doses, ${ }^{15}$ thus making GLP-1 interesting as a therapeutic option in T2DM.

GLP-1 is a 30-amino acid polypeptide produced in the endocrine L-cells of the intestinal epithelium, as a product of proglucagon gene expression. ${ }^{16}$ L-cells are located with the highest density in the ileum and the colon but can be found throughout the intestinal tract. ${ }^{9}$ GLP-1 is secreted rapidly in response to the ingestion of nutrients, with a noticeable response after 10 minutes. ${ }^{16}$

The enzyme DPP-4 is responsible for the rapid degradation and inactivation of GLP-1, resulting in a short 
elimination half-life $\left(\mathrm{t}_{1 / 2}\right)$ of native GLP-1 of $1-1.5$ minutes. ${ }^{17}$ Until now, a number of GLP-1RAs resistant to degradation by DPP-4 have been developed for therapeutic use. Furthermore, several different DPP-4 inhibitors are available for the treatment of patients with T2DM.

GLP-1 augments insulin secretion by the pancreatic $\beta$-cells in a glucose-dependent manner and has also been shown to enhance all steps of insulin biosynthesis as well as insulin gene transcription. ${ }^{13}$ The potentiating effect on insulin release is absent at plasma glucose levels below $4 \mathrm{mM}$, resulting in a low risk of hypoglycemia. ${ }^{18}$ In rodents, GLP-1 has trophic effects on $\beta$-cells, ${ }^{19}$ and in isolated human islets, GLP-1 has been demonstrated to inhibit apoptosis of $\beta$-cells. ${ }^{20}$ Glucagon secretion, and thereby, hepatic glucose production, is inhibited by GLP-1. ${ }^{21}$ Equivalent to the effect on insulin release, the suppression of glucagon secretion is glucose-dependent, and so, GLP-1 has no inhibitory effect on glucagon release at hypoglycemic plasma glucose concentrations, resulting in a preserved counter-regulatory glucagon response to hypoglycemia. ${ }^{18}$ It seems that the inhibition of glucagon secretion is as clinically important as the insulinotropic effect of GLP-1 for the treatment of hyperglycemia in patients with T2DM. ${ }^{22}$

Furthermore, GLP-1 decreases gastrointestinal motility, which, in combination with afferent signaling through the vagus nerve and activation of GLP-1 receptors in the central nervous system, promotes satiety and reduces food intake, thereby controlling or even reducing body weight. ${ }^{16,23}$ The delaying effect of GLP-1 on gastric emptying plays an important role in PPG control following short-term GLP-1 receptor activation. ${ }^{24}$

Finally, GLP-1 seems to have several beneficial effects in relation to the cardiovascular system. GLP-1 has been shown to improve left ventricular function in the failing and ischemic heart, ${ }^{25,26}$ to improve endothelial dysfunction in patients with T2DM and coronary heart disease, ${ }^{27}$ and moreover, seems to increase myocardial salvage after myocardial infarction. ${ }^{28}$ Additionally, GLP-1 has been found to cause a reduction in the postprandial rise in serum triglycerides and free fatty acids in healthy subjects. ${ }^{29}$ Furthermore, GLP-1 has been shown to exercise a blood pressure-lowering effect, ${ }^{30}$ presumably based on both its vasodilatory ${ }^{31}$ and diuretic properties. ${ }^{32}$

\section{Pharmacology of lixisenatide}

Lixisenatide is a GLP-1RA for once daily subcutaneous injection, developed by Sanofi under license from Zealand Pharma A/S (Copenhagen, Denmark). As previously described, market authorization approval was granted in February 2013. The peptide is based on the structure of exendin-4 (exenatide) and contains 44 amino acids. The modifications, compared with exendin- 4 , consist of a deletion of a proline residue and an addition of six lysine residues C-terminally (Figure 1). The time to maximal plasma concentration $\left(t_{\max }\right)$ has been reported to be approximately 2 hours in both healthy subjects and patients with T2DM. ${ }^{33}$ The mean maximal plasma concentration $\left(\mathrm{C}_{\text {max }}\right)$ with the intended $20 \mu \mathrm{g}$ once daily dosing was demonstrated to be $187 \mathrm{pg} / \mathrm{mL},{ }^{34}$ and $\mathrm{C}_{\max }$ has been reported to be higher in healthy subjects compared with patients with T2DM..$^{33}$ Lixisenatide is resistant to cleavage by DPP-4 but is, like native GLP-1, still subject to renal filtration. ${ }^{35}$ The resulting elimination $t_{1 / 2}$ in plasma is 2-3 hours, ${ }^{34,36}$ which is similar to the values obtained with exenatide. ${ }^{37}$ In patients with moderate renal impairment (creatinine clearance $30-50 \mathrm{~mL} / \mathrm{min}$ ), the clearance of lixisenatide is not affected, while in patients with severe renal impairment (creatinine clearance $<30 \mathrm{~mL} / \mathrm{min}$, not requiring renal dialysis), clearance is lowered by approximately $30 \%{ }^{38}$ Lixisenatide has been shown to lower the $\mathrm{C}_{\max }$ and to prolong the $t_{\max }$ of concomitantly administered oral warfarin, acetaminophen, and ethinyl estradiol. However, the extent of absorption (area under curve) was not shown to be significantly affected, which is consistent with a delaying effect on gastric emptying. ${ }^{39,40}$

In early binding studies, lixisenatide demonstrated a fourfold higher affinity for the human GLP-1 receptor when compared with native GLP-1..$^{41}$ This affinity is claimed to be superior to that of the similar compound exenatide, though no head-to-head trials have been published. ${ }^{42}$ In a 13 -week randomized, placebo-controlled trial, the efficacy of lixisenatide with respect to glycemic control was shown to reach a plateau at a dose of $20 \mu \mathrm{g}$ once daily. ${ }^{43}$ The optimal dose of $20 \mu \mathrm{g}$ once daily differs from the twice-daily administration of exenatide. This suggests a longer duration of action as compared with exenatide despite a similar elimination $t_{1 / 2}$,

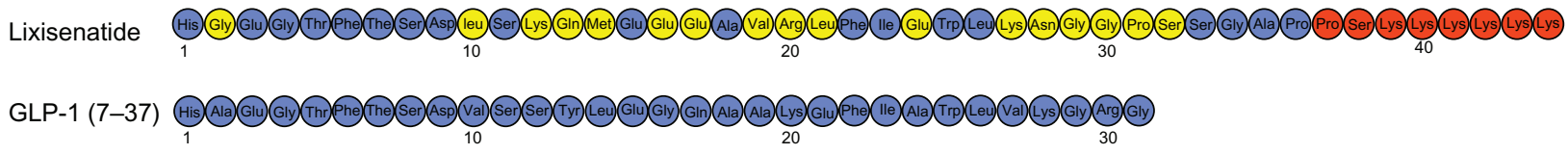

Figure I Structure of lixisenatide.

Notes: The yellow circles illustrate differences in amino acids compared with native GLP-I, and the red circles are differences compared with exendin-4. Abbreviation: GLP-I, glucagon-like peptide-I. 
which could reflect the difference in affinity for the GLP-1 receptor between the two peptides.

Lixisenatide activates the GLP-1 receptor and thereby generates the range of physiological effects generated by GLP-1. As described earlier, these consist of increased insulin secretion, inhibition of glucagon secretion, and decreased gastrointestinal motility alongside the promotion of satiety and several promising cardiovascular effects. Although lixisenatide stimulates insulin secretion, its marked effect on postprandial blood glucose levels seems mainly to be mediated through the inhibition of gastric emptying. ${ }^{44}$

\section{Clinical study program}

Lixisenatide has been evaluated in a clinical study program entitled GetGoal. Several different studies have now been completed, and many of the results have been published as either abstracts or full-length publications. Furthermore, there are a number of on-going trials for which results are being awaited. An overview of the studies with already published results can be found in Table 1 . The vast majority of the listed studies had the change in $\mathrm{HbA}_{1 \mathrm{c}}$ from baseline as the primary outcome. $\mathrm{HbA}_{1 \mathrm{c}}$ can be used as an estimate of average blood glucose levels during the preceding 2-3 months. ${ }^{45}$ Fasting plasma glucose (FPG) and PPG were both frequently listed as secondary outcomes. The change in bodyweight was also an outcome measure in most of the studies. Finally, many of the studies reported safety and tolerability data.

\section{Glycemic control Change in $\mathrm{HbA}_{\mathrm{Ic}}$}

Results from nine studies in the GetGoal program with $\mathrm{HbA}_{1 \mathrm{c}}$ as primary outcome have so far been presented (Table 2). The $\mathrm{HbA}_{1 \mathrm{c}}$ at baseline was approximately $8 \%-8.5 \%$ in these studies. In the GetGoal-Duo 1 study, the average $\mathrm{HbA}_{1 \mathrm{c}}$ was initially $8.6 \%$ at screening but had decreased to $7.6 \%$ at randomization after the run-in treatment with insulin glargine. ${ }^{46}$ In eight out of nine studies, lixisenatide was compared with placebo. This was done in different regimes with respect to dosage titration and time of day for administration. In the studies, lixisenatide was used as both monotherapy and as add-on to metformin, sulfonylureas, glitazones, insulin, and various combinations of these antidiabetic drugs. The GetGoal-X study compared lixisenatide with exenatide (Byetta) as add-on to metformin.

In these various trials, lixisenatide was shown to reduce $\mathrm{HbA}_{1 \mathrm{c}}$ between $0.32 \%$ and $0.88 \%$ when compared with placebo. The smallest reductions of $0.32 \%$ and $0.36 \%$ were seen in the GetGoal-Duol and the GetGoal-L study, respectively. ${ }^{46,47}$ In the GetGoal-Duo 1 study, this could have been due to a lower $\mathrm{HbA}_{1 \mathrm{c}}$ at randomization and additionally, a decrease in the daily basal insulin dose of $2.2 \mathrm{IU}$ in patients treated with lixisenatide as compared with the placebo group. Along these lines, the patients treated with lixisenatide, when compared with controls, either had substantial reductions in daily basal insulin dose (eg, the GetGoal-L, a reduction of 5.6 versus [vs] $1.9 \mathrm{IU})$ in combination with minor changes in $\mathrm{HbA}_{1 \mathrm{c}}$, or a smaller reduction in daily basal insulin dose (1.4 vs $0.1 \mathrm{IU}$ ) combined with a larger reduction in $\mathrm{HbA}_{1 \mathrm{c}}$, as observed in the GetGoal-L-Asia study. ${ }^{48}$

There was no readily apparent correlation between the obtained reductions in $\mathrm{HbA}_{1 \mathrm{c}}$ and the specific combinations of antidiabetic drugs in the nine studies. In general, significantly more patients treated with lixisenatide compared with placebo reached the defined target of $\mathrm{HbA}_{1 \mathrm{c}}$ below $7.0 \%$.

The primary outcome of the GetGoal-X study ${ }^{49}$ was to establish the noninferiority of lixisenatide to twice daily exenatide (Byetta) as add-on therapy to metformin, in terms of $\mathrm{HbA}_{1 \mathrm{c}}$ reduction. Both lixisenatide and exenatide reduced $\mathrm{HbA}_{1 \mathrm{c}}$ significantly, by $0.79 \%$ and $0.96 \%$, respectively. Thus, despite a statistically significant difference of $0.17 \%$ (95\% confidence interval: $0.03 \%-0.30 \%$ ) in $\mathrm{HbA}_{1 \mathrm{c}}$ reduction, noninferiority was claimed because the upper limit confidence interval for the estimate did not exceed the noninferiority margin of $0.4 \%$. Similar proportions of patients in the two treatment groups achieved the target $\mathrm{HbA}_{1 \mathrm{c}}$ below $7.0 \%$ or $6.5 \%$.

In another study, lixisenatide was reported to have a significantly smaller effect on $\mathrm{HbA}_{1 \mathrm{c}}$ compared with liraglutide, with reductions of $0.32 \%$ and $0.51 \%(P<0.01)$, respectively. ${ }^{50}$ However, the duration of this study was only 4 weeks, which could question the relevance of the chosen outcome measures, considering that $\mathrm{HbA}_{1 \mathrm{c}}$ is an estimate of average blood glucose levels over the preceding 2-3 months.

In the GetGoal-M study, ${ }^{51}$ lixisenatide was administered either before breakfast or dinner in order to assess whether the administration time of day was important for reductions in $\mathrm{HbA}_{1 \mathrm{c}}$. No significant difference between the two groups treated with lixisenatide at different times was observed, although a tendency towards higher effect with morning administration was seen $\left(\mathrm{HbA}_{1 \mathrm{c}}\right.$ reduced with $0.49 \%$ vs $0.37 \%$ ).

A meta-analysis based on six of the trials from the GetGoal program compared the effect of lixisenatide in different age groups and found comparable and significant $\mathrm{HbA}_{1 \mathrm{c}}$ reductions in all groups (Figure 3). ${ }^{52}$ 


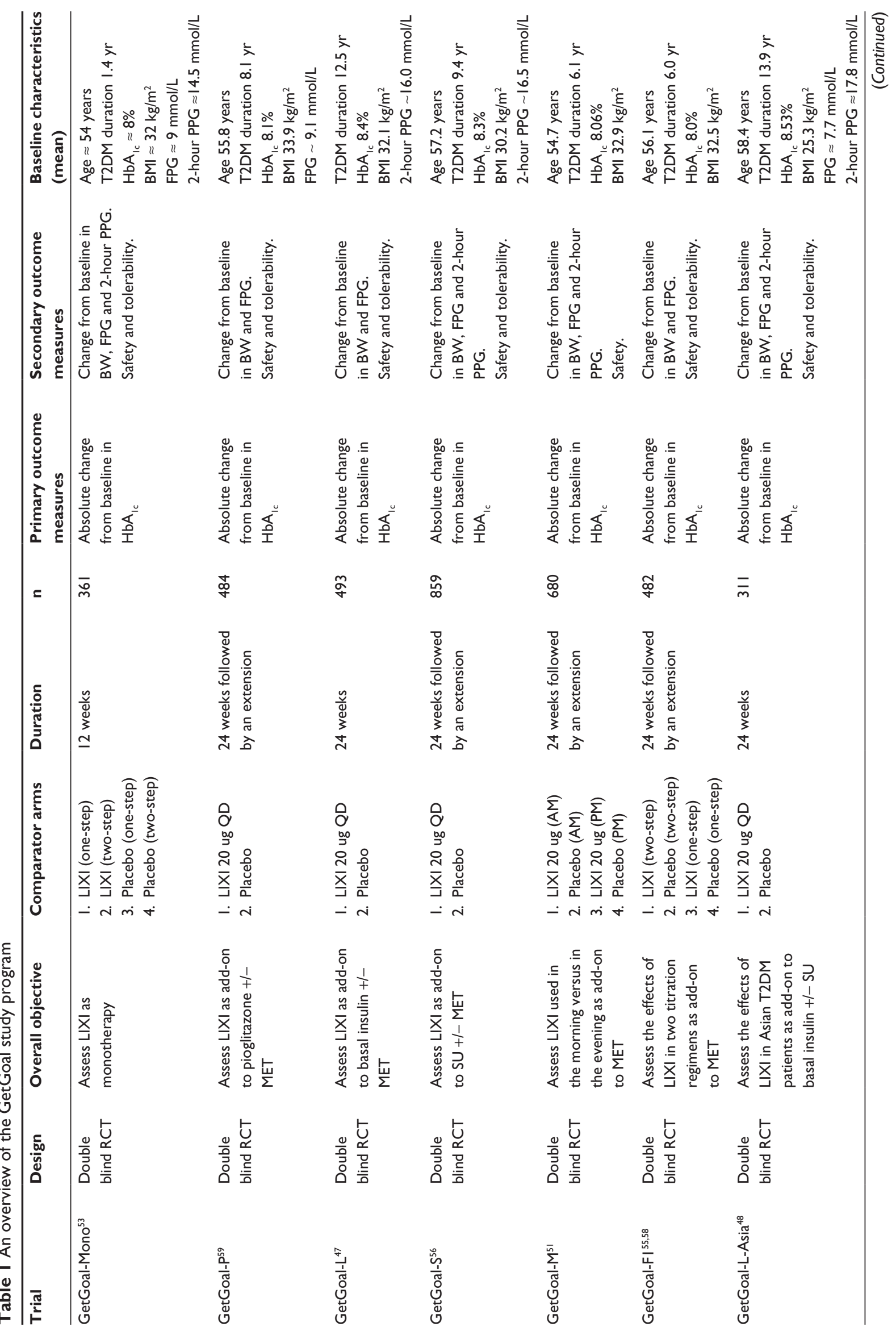




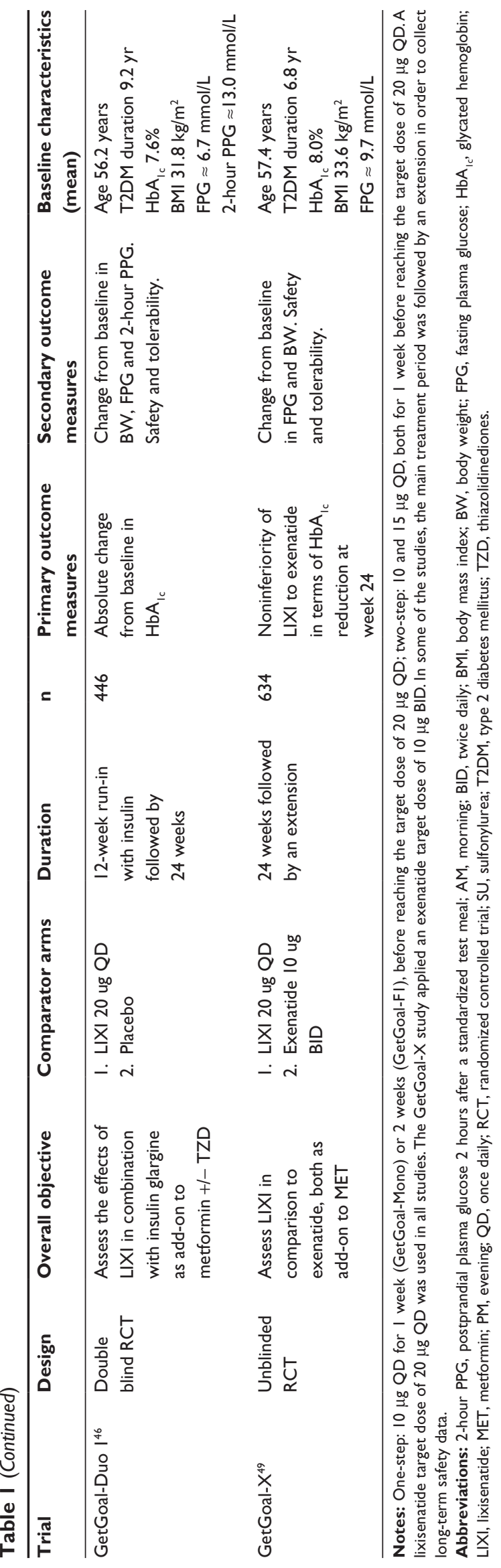

\section{FPG and PPG}

A number of studies from the GetGoal program have so far reported results regarding the effect of lixisenatide on FPG and PPG. GetGoal-X has compared lixisenatide with exenatide, whereas treatment with placebo was used as the control in the remaining studies. As previously described, the studies include several different combinations of antidiabetic treatments (see Table 1).

Treatment with lixisenatide, as compared with placebo, generally resulted in a significant decrease in FPG. The obtained range of decrease from baseline was between 0.6 and $1.1 \mathrm{mmol} / \mathrm{L}$. The GetGoal-Duo $1^{46}$ was the only placebocontrolled trial with no observed effect of lixisenatide on FPG. In fact, a small rise in FPG was seen in both the treatment and the control groups in this study. It has to be noted that the baseline FPG of $6.6 \mathrm{mmol} / \mathrm{L}$ in this study was by far the lowest in the group of trials reporting results on FPG, and this could be an explanation for the absent effect. In comparison, the FPG at baseline was approximately $9.0 \mathrm{mmol} / \mathrm{L}$ in the GetGoal-Mono study ${ }^{53}$ that had the largest observed decrease (of $1.1 \mathrm{mmol} / \mathrm{L}$ ) in FPG. In the GetGoal-X study, ${ }^{49}$ both lixisenatide and exenatide resulted in a significant decrease in FPG, from baselines of 1.2 and $1.4 \mathrm{mmol} / \mathrm{L}$, respectively. ${ }^{49}$ Thus, no significant difference in effect between the two treatments was observed. In contrast, liraglutide demonstrated a greater reduction in FPG compared with lixisenatide $(1.3$ vs $0.3 \mathrm{mmol} / \mathrm{L})(P<0.01) .^{50}$

Results from the GetGoal study program indicate that lixisenatide has a pronounced effect on postprandial glycemic control. Compared with placebo, significant decreases (of 3.2-7.2 $\mathrm{mmol} / \mathrm{L}$ ) in PPG from baseline have been observed. The PPG values were measured 2 hours after a standardized test meal. The lowest reported effect was seen in the GetGoal Duo-1 study. Again, the characteristics of the patients at baseline could at least partly help explain the difference between studies. In the GetGoal Duo-1 study, the average PPG at baseline was $13 \mathrm{mmol} / \mathrm{L}$, whereas the GetGoal-L-Asia study had the largest observed effect on PPG and also had the highest baseline PPG value (of $18 \mathrm{mmol} / \mathrm{L}$ ). ${ }^{48}$

A head-to-head trial with the main objective of comparing the effect of lixisenatide and liraglutide on PPG excursions was not part of the original GetGoal program but was also conducted by Sanofi. The patients included in the study had a baseline maximum PPG excursion of $4.9 \mathrm{mmol} / \mathrm{L}$, which was reduced to 1.0 and $3.5 \mathrm{mmol} / \mathrm{L}(P<0.01)$ after treatment with lixisenatide and liraglutide, respectively. ${ }^{50}$ Furthermore, the area under the plasma glucose concentration curve in a 4-hour period after the start of the standardized breakfast 
Table 2 Efficacy outcomes from the GetGoal study program

\begin{tabular}{|c|c|c|c|c|}
\hline Study & $\begin{array}{l}\text { HbA } \\
\text { LS mean difference } \\
\text { (Lixi vs placebo) }\end{array}$ & $\begin{array}{l}\text { FPG } \\
\text { LS mean difference } \\
\text { (Lixi vs placebo) }\end{array}$ & $\begin{array}{l}\text { 2-hour PPG } \\
\text { LS mean difference } \\
\text { (Lixi vs placebo) }\end{array}$ & $\begin{array}{l}\text { Weight } \\
\text { LS mean difference } \\
\text { (Lixi vs placebo) }\end{array}$ \\
\hline \multicolumn{5}{|l|}{ GetGoal-Mono ${ }^{53}$} \\
\hline One-step doses titration & $-0.66 \%(P<0.01)$ & $-1 . \mathrm{l} \mathrm{mmol} / \mathrm{L}(P<0.0 \mathrm{I})$ & $-4.8 \mathrm{mmol} / \mathrm{L}(-6.3 ;-3.4)$ & $\sim 0.0 \mathrm{~kg}$ \\
\hline Two-step doses titration & $-0.54 \%(P<0.0 \mathrm{I})$ & $-0.9 \mathrm{mmol} / \mathrm{L}(P<0.0 \mathrm{I})$ & $-3.9 \mathrm{mmol} / \mathrm{L}(-5.4 ;-2.4)$ & $\sim 0.0 \mathrm{~kg}$ \\
\hline GetGoal-P 59 & $-0.56 \%(-0.73 ;-0.39)$ & $-0.8 \mathrm{mmol} / \mathrm{L}(-1.2 ;-0.5)$ & & $-0.4 \mathrm{~kg}(-1.0 ; 0.2)$ \\
\hline GetGoal-L ${ }^{47}$ & $-0.36 \%(-0.55 ;-0.17)$ & & $-3.8 \mathrm{mmol} / \mathrm{L}(-4.7 ;-2.9)$ & $-1.3 \mathrm{~kg}(-1.8 ;-0.8)$ \\
\hline GetGoal-S ${ }^{56}$ & $-0.74 \%(-0.87 ;-0.62)$ & $-0.6 \mathrm{mmol} / \mathrm{L}(P<0.0 \mathrm{l})$ & $-6.0 \mathrm{mmol} / \mathrm{L}(-6.9 ;-5.0)$ & $-0.8 \mathrm{~kg}(P<0.0 \mathrm{I})$ \\
\hline \multicolumn{5}{|l|}{ GetGoal-M ${ }^{51}$} \\
\hline AM administration & $-0.49 \%(P<0.0 \mathrm{I})$ & $-0.9 \mathrm{mmol} / \mathrm{L}(P<0.05)$ & $-4.5 \mathrm{mmol} / \mathrm{L}(-5.7 ;-3.4)$ & $-0.4 \mathrm{~kg}(P>0.05)$ \\
\hline PM administration & $-0.37 \%(P<0.01)$ & $-0.6 \mathrm{mmol} / \mathrm{L}(P<0.05)$ & & $-0.4 \mathrm{~kg}(P>0.05)$ \\
\hline \multicolumn{5}{|l|}{ GetGoal-FI 55,58} \\
\hline One-step doses titration & $-0.49 \%(P<0.01)$ & $-0.7 \mathrm{mmol} / \mathrm{L}(P<0.0 \mathrm{I})$ & & $-1.0 \mathrm{~kg}(P<0.0 \mathrm{I})$ \\
\hline Two-step doses titration & $-0.41 \%(P<0.0 \mathrm{I})$ & $-0.7 \mathrm{mmol} / \mathrm{L}(P<0.0 \mathrm{I})$ & & $-1.1 \mathrm{~kg}(P<0.0 \mathrm{I})$ \\
\hline GetGoal-L-Asia ${ }^{48}$ & $-0.88 \%(-1.12 ;-0.65)$ & $-0.7 \mathrm{mmol} / \mathrm{L}(P<0.05)$ & $-7.8 \mathrm{mmol} / \mathrm{L}(-8.9 ;-6.8)$ & $-0.4 \mathrm{~kg}(-0.9 ; 0.1)$ \\
\hline \multirow[t]{2}{*}{ GetGoal-Duo I ${ }^{46}$} & $-0.32 \%(-0.46 ;-0.17)$ & $-0.1 \mathrm{mmol} / \mathrm{L}(-0.5 ; 0.2)$ & $-3.2 \mathrm{mmol} / \mathrm{L}(-4.0 ;-2.4)$ & $-0.9 \mathrm{~kg}(-1.4 ;-0.4)$ \\
\hline & Lixi vs exenatide & Lixi vs exenatide & Lixi vs exenatide & Lixi vs exenatide \\
\hline GetGoal-X ${ }^{49}$ & $0.17 \%(0.03 ; 0.30)$ & $0.2 \mathrm{mmol} / \mathrm{L}(-0 . \mathrm{I} ; 0.5)$ & & $1.0 \mathrm{~kg}(0.5 ; 1.6)$ \\
\hline
\end{tabular}

Notes: One-step titration: $10 \mu \mathrm{g}$ once daily for I week (GetGoal-Mono) or 2 weeks (GetGoal-FI), before reaching the target dose of $20 \mu g$; two-step titration: $10 \mu g$ once daily for I week followed by $15 \mu \mathrm{g}$ for I week, before reaching the target dose of $20 \mu \mathrm{g}$. The listed confidence intervals are at the $95 \%$ level. A lixisenatide target dose of $20 \mu \mathrm{g}$ once daily was used in all studies. The GetGoal-X study applied an exenatide target dose of $10 \mu \mathrm{g}$ twice daily.

Abbreviations: 2-hour PPG, postprandial plasma glucose 2 hours after a standardized test meal; AM, morning; FPG, fasting plasma glucose; HbA ${ }_{1 c}$, glycated hemoglobin; lixi, lixisenatide; LS, least squares; PM, evening; vs, versus.
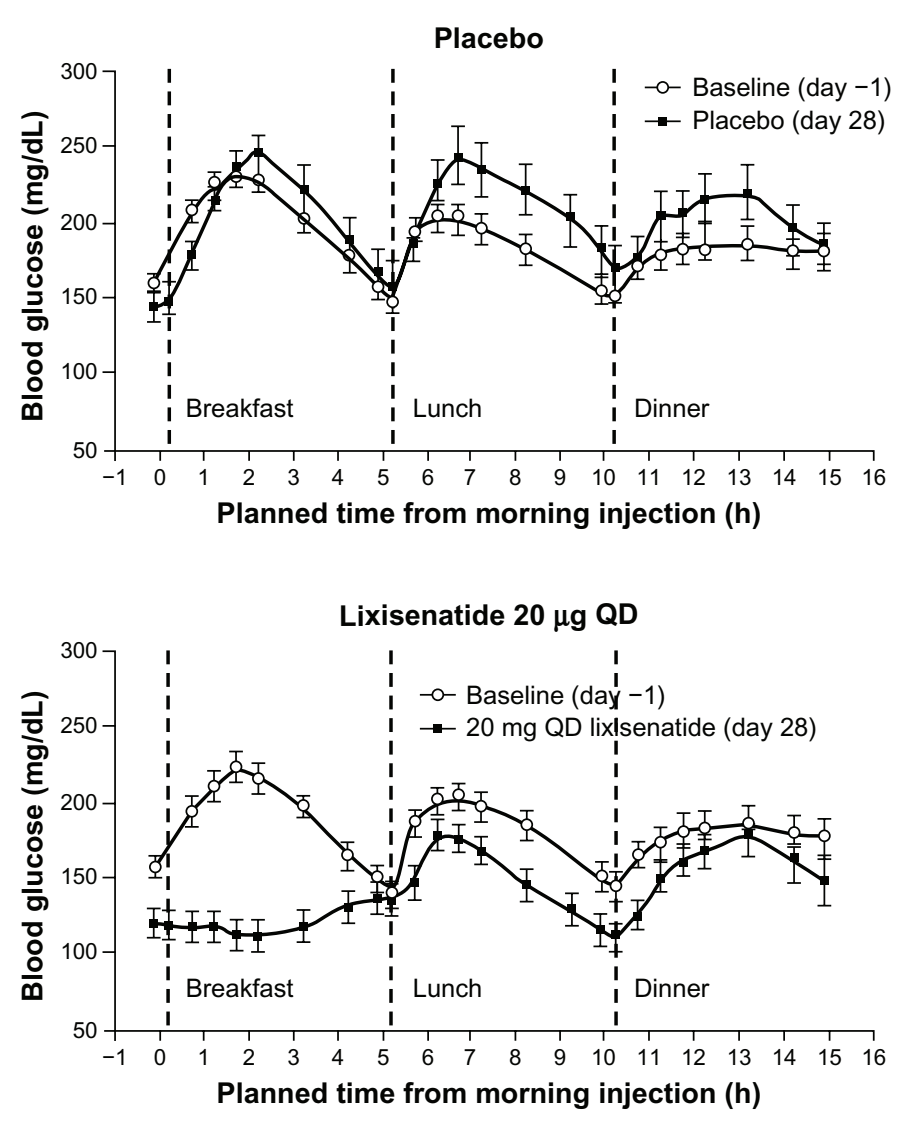
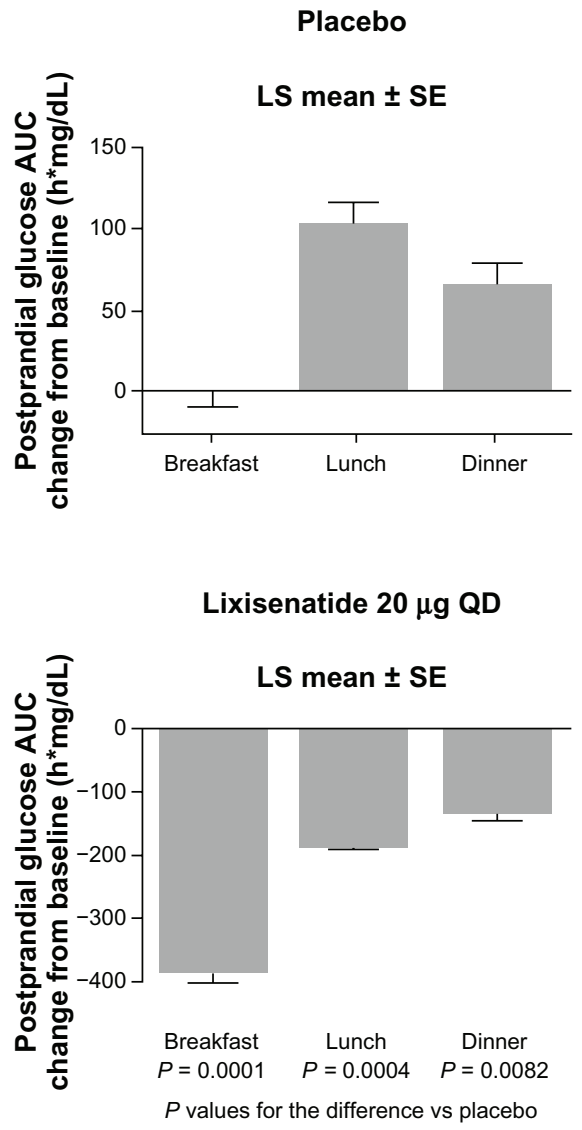

Figure 2 Mean blood glucose concentrations in patients with T2DM after administration of lixisenatide or placebo.

Note: Republished with permission of American Diabetes Association, from Clinical potential of lixisenatide once daily treatment for type 2 diabetes mellitus, Lorenz et al., Diabetes, 2012,6I; permission conveyed through Copyright Clearance Center, Inc.

Abbreviations: AUC, area under the curve; LS, least squares; QD, once daily; SE, standard error; T2DM, type 2 diabetes mellitus; vs, versus. 
test meal was significantly reduced following treatment with lixisenatide as compared with liraglutide. The study thereby found lixisenatide to have a significantly larger effect on PPG than liraglutide.

A study by Lorenz et al, ${ }^{54}$ presented at the scientific sessions of the American Diabetes Association 2012 meeting, tested the effect of a morning administration of lixisenatide on postprandial glycemia throughout the day. The largest effect on PPG was seen after breakfast, in accordance with the relatively short elimination $t_{1 / 2}$ of lixisenatide. Although smaller, the effect on PPG observed after lunch and dinner was still improved compared with placebo (Figure 2). Thus, it seems that lixisenatide exercises the most pronounced effect on PPG following the first meal after administration of the drug. The interpretation of this result was that the marked PPG-effect of lixisenatide mainly reflected the delaying effect on gastric emptying; the same interpretation was put forth and discussed by Distiller and Ruus. ${ }^{34}$ This suggests a possible advantage of administration of lixisenatide in conjunction with the main meal of the day, an assumption that still needs to be tested in clinical settings. Besides the effect on gastric emptying, lixisenatide also increases first-phase insulin secretion by almost threefold, thereby accelerating glucose disposition in subjects with early-stage T2DM. ${ }^{36}$ This insulinotropic effect could also contribute to the improvement in postprandial glycemic control seen after treatment with lixisenatide.

\section{Weight}

Nine studies in the GetGoal program have so far reported results on change in body weight after treatment with lixisenatide. In these studies, the effect of lixisenatide was compared with both placebo and exenatide. Furthermore, one study has reported results of lixisenatide vs liraglutide, with respect to change in body weight. Body mass index (BMI) at baseline was between 30 and $34 \mathrm{~kg} / \mathrm{m}^{2}$, except in the GetGoal-L-Asia study that had an Asian study population with a BMI at baseline of $25 \mathrm{~kg} / \mathrm{m}^{2}$ (Table 1 ).

The eight placebo-controlled trials found diverse effects of lixisenatide, with changes in body weight in the range of -2.7 to $+0.3 \mathrm{~kg}$ and reductions between -1.3 and $0.0 \mathrm{~kg}$, when compared with placebo (Table 2). In four of the studies, patients were treated with sulfonylurea or insulin, both of which can cause weight gain. A statistically significant placebo-adjusted decrease in body weight was reported in the GetGoal-L, GetGoal-Duo 1, GetGoal-S, and the GetGoalF1 studies. ${ }^{46,47,55,56}$ In three of these studies, lixisenatide was used as add-on to insulin or sulfonylurea, but increase in bodyweight was only observed in the GetGoal-Duo 1 study, which found increases after treatment with lixisenatide and placebo, of $0.3 \mathrm{~kg}$ and $1.2 \mathrm{~kg}$, respectively. ${ }^{46}$

In the GetGoal-X study, ${ }^{49}$ exenatide demonstrated a more pronounced effect on body weight than did lixisenatide. This study reported the two drugs to cause significant weight reductions from baseline, of 4.0 and $3.0 \mathrm{~kg}$, respectively. Thus, the mean difference was $1.0 \mathrm{~kg}$ (95\% confidence interval: $0.5-1.6)$, in favor of exenatide. ${ }^{49}$ The head-to-head trial comparing lixisenatide and liraglutide mentioned above found a decrease in body weight of 1.6 and $2.4 \mathrm{~kg}$ after 4 weeks of treatment with lixisenatide and liraglutide, respectively $(P<0.01){ }^{50}$

\section{Safety and tolerability Clinical safety of lixisenatide}

All of the trials in the GetGoal program have reported results concerning the safety of treatment with lixisenatide (Table 3).

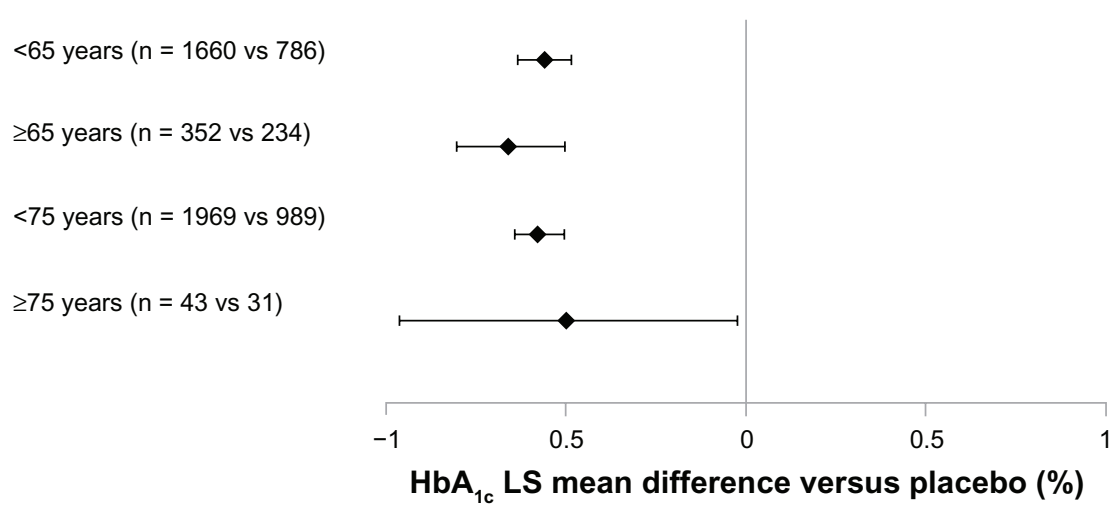

Figure 3 LS mean difference in $\mathrm{HbA}_{\mathrm{Ic}}$ change with lixisenatide versus (vs) placebo from a meta-analysis for the pooled data of six Phase III studies.

Notes: Error bars represent $95 \%$ confidence interval. Data from the main treatment period of the included studies (GetGoal-Mono [I2 weeks], GetGoal-M, -FI, -S, -L, -L-Asia [all 24 weeks]) - mITT population.

Copyright $@$ ( 2012, Efficacy and safety of lixisenatide in elderly (>65 years) and very elderly (>75 years) patients with type 2 diabetes: an analysis from the GetGoal phase 3 program [Poster], Raccah D, Miossec P, Esposito V, Niemoeller E, Cho M, Gerich J 48th EASD Annual Meeting I - 5 October 20I2. P8I5.

Abbreviations: $\mathrm{HbA}_{\mathrm{Ic}}$, glycated hemoglobin; LS, least squares; mITT, modified intent-to-treat; vs, versus. 
Table 3 Safety data from the GetGoal study program

\begin{tabular}{|c|c|c|c|c|c|c|c|c|c|c|}
\hline \multirow[t]{2}{*}{ Study } & \multicolumn{2}{|c|}{ AE (\%) } & \multicolumn{2}{|c|}{ SAE (\%) } & \multicolumn{2}{|c|}{$\begin{array}{l}\text { Hypoglycemic } \\
\text { event (\%) }\end{array}$} & \multicolumn{2}{|c|}{ Nausea (\%) } & \multicolumn{2}{|c|}{ Vomiting (\%) } \\
\hline & Lixi & PBO & Lixi & PBO & Lixi & PBO & Lixi & PBO & Lixi & PBO \\
\hline GetGoal-Mono ${ }^{53}$ & & 45.1 & & 4.1 & & 1.6 & & 4.1 & & 0.0 \\
\hline One-step titration & 54.6 & & 0.0 & & 0.8 & & 20.2 & & 6.7 & \\
\hline Two-step titration & 52.5 & & 0.8 & & 2.5 & & 24.2 & & 7.5 & \\
\hline GetGoal-P59 & 72.4 & 72.7 & 2.5 & 1.9 & 3.4 & 1.2 & 23.5 & 10.6 & 6.8 & 3.7 \\
\hline GetGoal-L ${ }^{47}$ & 73.5 & 68.3 & 3.7 & 4.2 & 27.7 & 21.6 & 26.2 & 8.4 & 8.2 & 0.6 \\
\hline GetGoal-S ${ }^{56}$ & 68.3 & 61.1 & 3.5 & 5.6 & 15.3 & 12.3 & 25.3 & 7.0 & 8.7 & 3.5 \\
\hline GetGoal-M ${ }^{51}$ & & 60.0 & & 1.2 & & 0.6 & & 7.6 & & 2.9 \\
\hline AM adm & 69.4 & & 2.0 & & 2.4 & & 22.7 & & 9.4 & \\
\hline PM adm & 69.4 & & 3.1 & & 5.1 & & 21.2 & & 13.3 & \\
\hline GetGoal-FI ${ }^{55,58}$ & & 86.3 & & 13.8 & & 7.5 & & 8.1 & & 0.6 \\
\hline One-step titration & 85.7 & & 9.9 & & 3.7 & & 29.2 & & 13.0 & \\
\hline Two-step titration & 87.6 & & 13.0 & & 7.5 & & 38.5 & & 18.0 & \\
\hline GetGoal-L-Asia ${ }^{48}$ & 89.0 & 70.1 & 6.5 & 5.7 & 42.9 & 23.6 & 39.6 & 4.5 & 18.2 & 1.9 \\
\hline GetGoal-Duo I ${ }^{46}$ & 79.8 & 68.2 & 7.6 & 4.5 & 20.2 & 11.7 & 27.4 & 4.9 & 9.4 & 1.3 \\
\hline Study & Lixi & exen & Lixi & exen & Lixi & exen & Lixi & exen & Lixi & exen \\
\hline GetGoal-X ${ }^{49}$ & 69.5 & 72.2 & 2.8 & 2.2 & 2.5 & 7.9 & 24.5 & 35.1 & 10.1 & 13.3 \\
\hline
\end{tabular}

Notes: Hypoglycemic event was defined as symptoms of hypoglycemia with accompanying blood glucose $<3.3 \mathrm{mM}$ or prompt recovery with carbohydrate. One-step titration: $10 \mu \mathrm{g}$ once daily for I week (GetGoal-Mono) or 2 weeks (GetGoal-FI), before reaching the target dose of $20 \mu \mathrm{g}$; two-step titration: I0 $\mu \mathrm{g}$ once daily for I week followed by $15 \mu \mathrm{g}$ for I week, before reaching the target dose of $20 \mu \mathrm{g}$. A lixisenatide target dose of $20 \mu \mathrm{g}$ once daily was used in all studies. The GetGoal-X study applied an exenatide target dose of $10 \mu \mathrm{g}$ twice daily.

Abbreviations: AE, adverse event; AM adm, morning administration; exen, exenatide; lixi, lixisenatide; PBO, placebo; PM adm, evening administration; SAE, serious adverse event.

Additionally, treatment discontinuation rates among patients were stated in most of these studies (Table 4). The overall frequency of adverse events (AEs) to treatment with lixisenatide varied from $52 \%$ in the GetGoal-Mono study to $89 \%$ in the GetGoal-L-Asia study. Likewise, the occurrence of serious adverse events (SAEs) differed substantially between these same two studies, with rates of $0 \%$ and $13 \%$, respectively. ${ }^{48,53}$

The most frequently reported AEs to treatment with GLP1RAs are related to the gastrointestinal system, with nausea and vomiting being by far, the most frequent. Gastrointestinal

Table 4 Discontinuation data from the GetGoal study program

\begin{tabular}{|c|c|c|c|c|}
\hline \multirow[t]{2}{*}{ Study } & \multicolumn{2}{|c|}{ Discontinuation (\%) } & \multicolumn{2}{|c|}{ Discontinuation due to $\mathrm{AE}(\%)$} \\
\hline & Lixisenatide & Placebo & Lixisenatide & Placebo \\
\hline GetGoal-Mono ${ }^{53}$ & & 7.4 & & 0.8 \\
\hline One-step titration & 9.2 & & 2.5 & \\
\hline Two-step titration & 8.3 & & 4.2 & \\
\hline GetGoal-P59 & & & 6.5 & 5.0 \\
\hline GetGoal-L ${ }^{47}$ & & & 7.6 & 4.8 \\
\hline GetGoal-S ${ }^{56}$ & & & 9.8 & 4.9 \\
\hline \multicolumn{5}{|l|}{ GetGoal-M ${ }^{51}$} \\
\hline GetGoal-FI ${ }^{55,58}$ & & & & 5.6 \\
\hline One-step titration & & & 8.7 & \\
\hline Two-step titration & & & 11.8 & \\
\hline GetGoal-L-Asia $^{48}$ & 13.6 & 8.3 & 9.1 & 3.2 \\
\hline \multirow[t]{2}{*}{ GetGoal-Duo I ${ }^{46}$} & 13.0 & 5.0 & 8.5 & 3.6 \\
\hline & Lixisenatide & Exenatide & Lixisenatide & Exenatide \\
\hline GetGoal-X ${ }^{49}$ & 12.9 & 14.2 & 9.1 & 9.8 \\
\hline
\end{tabular}

Notes: One-step titration: $10 \mu \mathrm{g}$ once daily for I week (GetGoal-Mono) or 2 weeks (GetGoal-FI), before reaching the target dose of $20 \mu g$; two-step titration: $10 \mu \mathrm{g}$ once daily for I week followed by $15 \mu \mathrm{g}$ for I week, before reaching the target dose of $20 \mu \mathrm{g}$. A lixisenatide target dose of $20 \mu \mathrm{g}$ once daily was used in all studies. The GetGoal-X study applied an exenatide target dose of $10 \mu \mathrm{g}$ twice daily.

Abbreviation: $\mathrm{AE}$, adverse event. 
complaints most often occur within the first month of treatment and tend to diminish over the following weeks. ${ }^{53}$

Hypoglycemia is a feared AE to antidiabetic treatment and especially with insulin and the sulfonylureas. A limited risk of treatment-induced hypoglycemia in relation to lixisenatide would be expected when considering the glucose-dependent manner of effect. However, the risk of hypoglycemia must especially be taken into account when using lixisenatide in combination with other antidiabetic drugs and in particular, with insulin and sulfonylurea, which will very often be the case in clinical practice.

As expected, some patients in the clinical studies discontinued treatment before completing the planned follow up. In general, most of these discontinuations were associated with treatment-related AEs. The most relevant findings concerning safety and tolerability will be further elucidated in the following sections.

\section{Gastro-intestinal adverse effects}

The most frequent AE, nausea, was observed in as many as $20 \%-40 \%$ of patients treated with lixisenatide in the GetGoal program (Table 3 ). In the placebo-treated patients, nausea was much less common, with a range of $4 \%-11 \%$. Nausea in relation to lixisenatide was most frequently observed in the GetGoal-L-Asia study. An exclusively Asian population with a suggested more advanced disease due to longer duration of T2DM compared with patients in the remaining studies was listed as a possible explanation for the higher observed incidence. ${ }^{48}$ Additionally, the study population in the GetGoal-L-Asia study had a relatively low BMI $\left(25 \mathrm{~kg} / \mathrm{m}^{2}\right)$, which could have led to a relatively higher exposure of lixisenatide and thereby, a higher incidence of nausea.

Vomiting was in general, less frequently observed, with rates of $7 \%-18 \%$ and $0 \%-4 \%$ in patients treated with lixisenatide and placebo, respectively (Table 3). Again, the highest incidence was observed in the GetGoal-L-Asia study. It has been suggested that the incidence of gastrointestinal AEs can be reduced using a dose-escalation strategy. ${ }^{57}$ However, in both the GetGoal-Mono and in the GetGoal-F1 study, a trend towards higher incidence of gastrointestinal AEs following two-step titration compared with one-step titration, was observed (Table 3). ${ }^{53,58}$

In the GetGoal-X study, lixisenatide was found to cause less gastrointestinal AEs compared with exenatide. In this study, the incidence of nausea and vomiting in the lixisenatide-treated group was $25 \%$ and $10 \%$, respectively. The corresponding rates for patients treated with exenatide were $35 \%$ and $13 \%$ (Table 3 ). ${ }^{49}$
The head-to-head trial comparing lixisenatide and liraglutide as add-on to metformin found similar incidences of nausea (23\% vs $22 \%$ ) and vomiting (10\% vs $7 \%$ ) in the two treatment groups. Diarrhea seemed to be more frequent during treatment, with liraglutide having an incidence of $16 \%$ as compared with $3 \%$ for lixisenatide. ${ }^{50}$ In the GetGoal-X study, ${ }^{49}$ diarrhea was observed in $10 \%$ and $13 \%$ of patients treated with lixisenatide and exenatide, respectively. In the placebo-controlled trials of the GetGoal study program, diarrhea was observed in 7\%-9\% of patients treated with lixisenatide and 3\%-11\% of controls. Interestingly, in the GetGoal-P study, ${ }^{59}$ a higher occurrence of diarrhea was observed with placebo compared with lixisenatide treatment.

As previously described, the gastrointestinal AEs in relation to treatment with GLP-1 often tend to decrease within the first weeks of ongoing use. The GetGoal-Mono study stated that the gastrointestinal AEs diminished within 7 weeks of ongoing treatment, and the GetGoal-L, GetGoal-Duo 1, and GetGoal-L-Asia studies also described a spontaneous reduction in gastrointestinal AEs over time. ${ }^{46-48,53}$

\section{Hypoglycemia}

All studies in the GetGoal program reported results concerning hypoglycemic events. The applied definition of symptomatic hypoglycemia in these studies was: symptoms of hypoglycemia, with accompanying blood glucose $<3.3 \mathrm{mmol} / \mathrm{L}$ or prompt recovery after carbohydrate intake. Furthermore, severe hypoglycemia was defined as hypoglycemic episodes requiring assistance.

As previously described, the glucose-dependent effect of lixisenatide should in theory, confer a low risk of treatment-induced hypoglycemia. The GetGoal-Mono study ${ }^{53}$ confirmed this assumption. In this study, lixisenatide monotherapy caused symptomatic hypoglycemia in $0.8 \%$ and $2.5 \%$ of patients treated with lixisenatide one-step and two-step titration, respectively. A similar incidence of $1.6 \%$ was observed in the combined placebo group. No severe hypoglycemic events were reported in the GetGoal-Mono study. Both the frequency and severity of hypoglycemia in clinical trials seemed to be highly dependent on comedication with insulin or the sulfonylureas, as these drugs are known to raise serum insulin levels irrespective of the prevailing plasma glucose level. A limited frequency of hypoglycemia was seen in studies combining lixisenatide with metformin and the glitazones (GetGoal-P, GetGoal-M, and GetGoalF1). The highest frequency of symptomatic hypoglycemia in lixisenatide-treated patients in these studies was $7.5 \%$, and the reported incidences were in general, comparable with 
placebo (Table 3)..$^{51,58,59}$ Furthermore, no severe hypoglycemic events were reported in any of these studies.

The combination of treatment with lixisenatide and insulin in the GetGoal-L, ${ }^{47}$ GetGoal-L-Asia, ${ }^{48}$ and GetGoalDuo $1^{46}$ studies resulted in considerably more hypoglycemic events. Incidences of symptomatic hypoglycemia between $20 \%$ and $43 \%$ in lixisenatide-treated patients were reported in these studies. The frequency of symptomatic hypoglycemia was similar to that seen with placebo in the GetGoal-L study, whereas the incidence was almost doubled in comparison to that of placebo in the GetGoal-L-Asia and GetGoal-Duo 1 studies (Table 3). Symptomatic hypoglycemia was by far the most common in the GetGoal-L-Asia study, which could be explained by the fact that $70 \%$ of patients in this study, in addition to insulin, were treated with sulfonylureas. One $(0.4 \%)$ and four $(1.2 \%)$ cases of severe hypoglycemia in lixisenatide-treated patients were reported in the GetGoalDuo 1 and GetGoal-L studies, respectively. No cases were reported in the placebo-treated controls.

Lixisenatide was used as add-on to sulfonylurea in the GetGoal-S study. ${ }^{56}$ Comparable frequencies of symptomatic hypoglycemia ( $15 \%$ vs $12 \%$ ) were observed in the lixisenatide and placebo-treated patients. One case $(0.2 \%)$ of severe hypoglycemia was reported in the group treated with lixisenatide and none in relation to placebo. It has been suggested that sulfonylurea drugs may uncouple the glucose dependency of GLP- $1 .^{60}$ Whether this possible mechanism was responsible for the difference in observed cases of hypoglycemia is unknown. However, the data showed that the risk of hypoglycemia must be considered when using lixisenatide in combination with sulfonylurea and particularly, if additional treatment with insulin is applied.

In the GetGoal-X study, ${ }^{49}$ significantly fewer patients treated with lixisenatide experienced a symptomatic hypoglycemic event as compared with exenatide. The incidences of hypoglycemia were $2.5 \%$ and $7.9 \%(P<0.05)$. No cases of severe hypoglycemia were reported. In the head-to-head study between lixisenatide and liraglutide, no cases of either symptomatic or severe hypoglycemia were reported. ${ }^{50}$

\section{Other adverse events}

No cases of suspected pancreatitis have been observed during treatment with lixisenatide. A total number of four allergic reactions in about 2500 patients treated with lixisenatide have been reported. One patient experienced angioedema $\mathrm{a}^{53}$ and the remaining three had urticarial reactions..$^{48,50,53}$ Other adverse events (eg, headache and dizziness) were in general, reported only slightly more often after treatment with lixisenatide compared with placebo.

The head-to-head trial comparing lixisenatide and liraglutide found these treatments to cause a change in heart rate, of -3.6 and +5.3 beats $/ \mathrm{min}$, respectively. The observed difference between treatments of 8.9 beats/min was significant. ${ }^{50} \mathrm{~A}$ different study reported no changes in heart rate following treatment with lixisenatide. ${ }^{43}$

\section{Antibody formation}

Two studies have discussed the clinical importance of anti-lixisenatide antibodies. In the GetGoal-Mono study, ${ }^{53}$ the development of antibodies was reported in approximately $60 \%$ of patients treated with $20 \mu \mathrm{g}$ lixisenatide once daily. In another study, antibodies were found in $43 \%$ of subjects treated with $10 \mu \mathrm{g}$ lixisenatide once daily and in $71 \%$ treated with $20 \mu \mathrm{g}$ twice daily. ${ }^{43}$ No relevant differences were reported in terms of safety and efficacy between antibodypositive and -negative patients in either of the two studies. None of the studies reported on the incidences of high-titer antibodies, which have been noted to better predict the clinical significance of antibodies to the similar GLP-1RA, exenatide. ${ }^{61}$

\section{Tolerability and patient satisfaction}

All studies in the GetGoal program except the GetGoal-M study provided information about patient discontinuation due to adverse events, which can be used as an expression of tolerability. A discontinuation rate due to AEs above $10 \%$ was only observed in patients treated with two-step titration in the GetGoal-F1 study. In the GetGoal-Mono study, AEs due to lixisenatide monotherapy caused discontinuation in less than $5 \%$ of patients. In the remaining studies, treatment with lixisenatide as add-on to various other antidiabetic drugs resulted in discontinuation due to AEs in 5\%-10\% of patients (Table 4). A tendency towards less discontinuation due to AEs in the control groups was observed in all of the placebo-controlled studies in the GetGoal program. Several of the studies stated that discontinuation due to AEs was mainly a result of nausea and vomiting. ${ }^{46-48,58,59}$ Furthermore, higher rates of overall discontinuation (all reasons) were reported following treatment with lixisenatide, as compared with placebo (Table 4).

Similar discontinuation rates were seen when comparing lixisenatide to the other available GLP-1RAs, exenatide and liraglutide. In the GetGoal-X study, ${ }^{49}$ treatment with lixisenatide and exenatide led to discontinuation due to AEs in 9.1\% and $9.8 \%$ of patients, respectively. The corresponding rates 
in the trial comparing lixisenatide and liraglutide were $2.6 \%$ and $2.8 \%$, respectively. ${ }^{50}$

GetGoal-X was the only study that directly addressed patient satisfaction in relation to treatment with lixisenatide. This was done using the Patient Assessment of Upper Gastrointestinal Disorders-Quality Of Life (PAGI-QOL) questionnaire that is a tool for assessing quality of life in patients with upper gastrointestinal disorders. Changes in the PAGI-QOL score of less than 0.4 in relation to treatment is described to be without any clinical relevance. ${ }^{62}$ The change from baseline in PAGI-QOL score did not differ between lixisenatide- and exenatide-treated patients, with absolute changes of -0.09 and -0.06 , respectively. ${ }^{49}$

A recently published review by Russell ${ }^{63}$ discussed patient satisfaction in relation to different incretin-based therapies. Despite the need for injections and a higher frequency of gastrointestinal side effects, a greater patient satisfaction was seen in relation to treatment with the GLP-1RAs liraglutide and exenatide in comparison with DPP-4 inhibitors. The author suggested a greater effect with respect to glycemic control and weight loss as the most likely explanation for this finding.

\section{Conclusion, place in therapy}

A dose of $20 \mu \mathrm{g}$ once daily administered before breakfast has been established as the most rational regimen of treatment with lixisenatide (Lyxumia). This regimen is similar to the once daily administration of liraglutide (Victoza) and differs from the twice daily (Byetta) and once weekly (Bydureon) administration of exenatide.

In the GetGoal Phase III study program, lixisenatide has demonstrated significant reduction in $\mathrm{HbA}_{1 \mathrm{c}}$, FPG, and PPG compared with placebo. The effect on glycemia was present for both monotherapy and in combination with insulin and various oral antidiabetic agents. Furthermore, a trend towards reduced body weight, in the range of $0.5-1.0 \mathrm{~kg}$ was observed. However, in several of the studies, the reported reductions in body weight were not statistically significant. Exenatide and liraglutide have been reviewed elsewhere, and these drugs were shown to reduce $\mathrm{HbA}_{1 \mathrm{c}}$ by about 1-2 percentage points and cause a weight loss of $\sim 2 \mathrm{~kg} \cdot{ }^{64} \mathrm{~A}$ recent meta-analysis concerning the efficacy of treatment with the various DPP-4 inhibitors has reported placebocontrolled reductions in $\mathrm{HbA}_{1 \mathrm{c}}$ and $\mathrm{FPG}$ of $0.5 \%-1.0 \%$ and $0.7-1.5 \mathrm{mmol} / \mathrm{L}$, respectively. ${ }^{65}$ Furthermore, the DDP-4 inhibitors were found to be weight neutral. ${ }^{65}$ Thus, the treatment effects of lixisenatide, in terms of $\mathrm{HbA}_{1 \mathrm{c}}, \mathrm{FPG}$, and body weight, seem to be very similar to the efficacy of treatment with DPP-4 inhibitors. However, it has to be noted that no direct comparisons have been carried out.
The potential of lixisenatide, in terms of PPG reduction, has been demonstrated in a direct comparison with liraglutide. The delaying effect on gastric emptying by GLP-1 has been shown to wane during continuous exposure, ${ }^{24}$ and this could very likely be the explanation for the significantly larger effect of the short-acting lixisenatide ( $\mathrm{t}_{1 / 2}=2-3$ hours) on PPG as compared with the longer acting liraglutide $\left(t_{1 / 2}=13\right.$ hours $)$. The clinical value of targeted treatment of PPG excursions still needs to be determined. As previously described, PPG has been recognized as a contributor to overall glycemic control, in terms of $\mathrm{HbA}_{1 \mathrm{c}}$, in patients with mild to moderate severity T2DM. In the GetGoal-Duo 1 study, a decrease in $\mathrm{HbA}_{1 \mathrm{c}}$ was observed without a corresponding decrease in FPG, which could indicate an important role of PPG when it comes to achieving overall glycemic control. Furthermore, PPG has been discussed as a potential therapeutic target with respect to achieving reduced cardiovascular morbidity in relation to T2DM. ${ }^{66}$

Based on the results from the GetGoal-X study and the comparison with liraglutide, it appears that liraglutide and possibly exenatide are superior to lixisenatide in terms of $\mathrm{HbA}_{1 \mathrm{c}}$ reduction. ${ }^{49,50}$ However, the GetGoal-X study claimed noninferiority of lixisenatide in comparison with exenatide, based on a defined noninferiority margin (95\% confidence interval of the difference not exceeding 0.4). Furthermore, the limited duration of the trial with liraglutide should be taken into account when interpreting the result of this study. The two studies demonstrated a superior reduction in body weight after treatment with exenatide and liraglutide as compared with lixisenatide. In addition, liraglutide was found to reduce FPG more than lixisenatide.

Nausea and vomiting were the most frequently observed adverse events in relation to treatment with lixisenatide. Although several studies listed nausea and vomiting as the main reasons for discontinuation of treatment, these events were in general reported to decrease within the first weeks of ongoing use. Hypoglycemic events after treatment with lixisenatide seemed to be highly dependent on comedication with insulin or the sulfonylureas, and the risk of hypoglycemia must be considered when applying these combinations of antidiabetic treatment. Similar rates of discontinuation were observed after treatment with lixisenatide, exenatide, and liraglutide.

Weighing the efficacy against the adverse events and the economic costs generated by a specific treatment is a rational approach when having to decide on a specific treatment, and when comparing across treatments with the same indication. At best, lixisenatide seems to be equivalent to the alternative GLP-1RAs, with respect to $\mathrm{HbA}_{1 \mathrm{c}}, \mathrm{FPG}$, and 
weight reduction. However, in direct comparisons, lixisenatide demonstrated a tendency towards fewer AEs. Considering the equal method of action, it is likely that the difference in efficacy and AEs is mainly a pharmacokinetic issue.

The combination of a substantial effect on PPG and a labeling of once daily administration is, however, a discerning factor compared with the GLP-1RAs already on the market. The combination of basal insulin, with its lowering effect on FPG, and lixisenatide, curtailing the postprandial glucose excursions, makes sense from a clinical point of view. Not surprisingly, lixisenatide is undergoing clinical development as a combination product with insulin glargine (Lantus ${ }^{\circledR}$; Sanofi). This treatment combination has been shown to substantially improve $\mathrm{HbA}_{1 \mathrm{c}}$, without weight gain, in the GetGoal-L, GetGoal-L-Asia, and the GetGoalDuo 1 studies. At present, unless lixisenatide is priced lower than the already available GLP-1RA alternatives, it appears that the main place in therapy for lixisenatide is in the combination with insulin glargine. The ongoing multicenter ELIXA study (evaluation of cardiovascular outcomes in patients with Type 2 Diabetes after Acute Coronary Syndrome during treatment with AVE0010 [Lixisenatide], NCT01147250) will determine the future potential of lixisenatide in preventing cardiovascular events and mortality, in patients with T2DM and recent acute coronary syndrome.

\section{Acknowledgments}

The authors would like to thank JP Kampmann for his critical appraisal of this manuscript.

\section{Disclosure}

The authors report no conflicts of interest in this work.

\section{References}

1. Wild S, Roglic G, Green A, Sicree R, King H. Global prevalence of diabetes: estimates for the year 2000 and projections for 2030. Diabetes Care. 2004;27(5):1047-1053.

2. Monnier L, Lapinski H, Colette C. Contributions of fasting and postprandial plasma glucose increments to the overall diurnal hyperglycemia of type 2 diabetic patients: variations with increasing levels of $\mathrm{HbA}(1 \mathrm{c})$. Diabetes Care. 2003;26(3):881-885.

3. Göke B. Islet cell function: alpha and beta cells - partners towards normoglycaemia. Int J Clin Pract Suppl. 2008;159:2-7.

4. Meier JJ, Nauck MA. Is the diminished incretin effect in type 2 diabetes just an epi-phenomenon of impaired beta-cell function? Diabetes. 2010;59(5):1117-1125.

5. Nathan DM, Buse JB, Davidson MB, et al; American Diabetes Association; European Association for the Study of Diabetes. Medical management of hyperglycaemia in type 2 diabetes mellitus: a consensus algorithm for the initiation and adjustment of therapy: a consensus statement from the American Diabetes Association and the European Association for the Study of Diabetes. Diabetologia. 2009;52(1):17-30.
6. Cubbon R, Kahn M, Kearney MT. Secondary prevention of cardiovascular disease in type 2 diabetes and prediabetes: a cardiologist's perspective. Int J Clin Pract. 2008;62(2):287-299.

7. Gaede P, Lund-Andersen H, Parving H-H, Pedersen O. Effect of a multifactorial intervention on mortality in type 2 diabetes. $N$ Eng $J$ Med. 2008;358(6):580-591.

8. Inzucchi SE, Bergenstal RM, Buse JB, et al. Management of hyperglycaemia in type 2 diabetes: a patient-centered approach. Position statement of the American Diabetes Association (ADA) and the European Association for the Study of Diabetes (EASD). Diabetologia. 2012;55(6): $1577-1596$.

9. Vilsbøll T, Holst JJ. Incretins, insulin secretion and Type 2 diabetes mellitus. Diabetologia. 2004;47(3):357-366.

10. Perley MJ, Kipnis DM. Plasma insulin responses to oral and intravenous glucose: studies in normal and diabetic subjects. J Clin Invest. 1967;46(12): 1954-1962.

11. Nauck MA, Homberger E, Siegel EG, et al. Incretin effects of increasing glucose loads in man calculated from venous insulin and C-peptide responses. J Clin Endocrinol Metab. 1986;63(2):492-498.

12. Holst JJ, Gromada J. Role of incretin hormones in the regulation of insulin secretion in diabetic and nondiabetic humans. Am J Physiol Endocrinol Metab. 2004;287(2):E199-E206.

13. Fehmann HC, Göke R, Göke B. Cell and molecular biology of the incretin hormones glucagon-like peptide-I and glucose-dependent insulin releasing polypeptide. Endocr Rev. 1995;16(3):390-410.

14. Vilsbøll T, Krarup T, Madsbad S, Holst JJ. Both GLP-1 and GIP are insulinotropic at basal and postprandial glucose levels and contribute nearly equally to the incretin effect of a meal in healthy subjects. Regul Pept. 2003;114(2-3):115-121.

15. Nauck MA, Bartels E, Orskov C, Ebert R, Creutzfeldt W. Additive insulinotropic effects of exogenous synthetic human gastric inhibitory polypeptide and glucagon-like peptide-1-(7-36) amide infused at near-physiological insulinotropic hormone and glucose concentrations. J Clin Endocrinol Metab. 1993;76(4):912-917.

16. Holst JJ. The physiology of glucagon-like peptide 1. Physiol Rev. 2007;87(4):1409-1439.

17. Deacon CF, Nauck MA, Toft-Nielsen M, Pridal L, Willms B, Holst JJ. Both subcutaneously and intravenously administered glucagon-like peptide I are rapidly degraded from the NH2-terminus in type II diabetic patients and in healthy subjects. Diabetes. 1995;44(9): $1126-1131$.

18. Nauck MA, Heimesaat MM, Behle K, et al. Effects of glucagon-like peptide 1 on counterregulatory hormone responses, cognitive functions, and insulin secretion during hyperinsulinemic, stepped hypoglycemic clamp experiments in healthy volunteers. J Clin Endocrinol Metab. 2002;87(3):1239-1246.

19. Egan JM, Bulotta A, Hui H, Perfetti R. GLP-1 receptor agonists are growth and differentiation factors for pancreatic islet beta cells. Diabetes Metab Res Rev. 2003;19(2):115-123.

20. Buteau J, El-Assaad W, Rhodes CJ, Rosenberg L, Joly E, Prentki M. Glucagon-like peptide-1 prevents beta cell glucolipotoxicity. Diabetologia. 2004;47(5):806-815.

21. Larsson H, Holst JJ, Ahrén B. Glucagon-like peptide-1 reduces hepatic glucose production indirectly through insulin and glucagon in humans Acta Physiol Scand. 1997;160(4):413-422.

22. Hare KJ, Knop FK. Incretin-based therapy and type 2 diabetes. Vitam Horm. 2010;84:389-413.

23. Flint A, Raben A, Astrup A, Holst JJ. Glucagon-like peptide 1 promotes satiety and suppresses energy intake in humans. J Clin Invest. 1998;101(3):515-520.

24. Nauck MA, Kemmeries G, Holst JJ, Meier JJ. Rapid tachyphylaxis of the glucagon-like peptide 1-induced deceleration of gastric emptying in humans. Diabetes. 2011;60(5):1561-1565.

25. Nikolaidis LA, Mankad S, Sokos GG, et al. Effects of glucagonlike peptide-1 in patients with acute myocardial infarction and left ventricular dysfunction after successful reperfusion. Circulation. 2004;109(8):962-965. 
26. Nikolaidis LA, Elahi D, Hentosz T, et al. Recombinant glucagon-like peptide-1 increases myocardial glucose uptake and improves left ventricular performance in conscious dogs with pacing-induced dilated cardiomyopathy. Circulation. 2004;110(8):955-961.

27. Nyström T, Gutniak MK, Zhang Q, et al. Effects of glucagon-like peptide-1 on endothelial function in type 2 diabetes patients with stable coronary artery disease. Am J Physiol Endocrinol Metab. 2004; 287(6):E1209-E1215.

28. Lønborg J, Vejlstrup N, Kelbæk H, et al. Exenatide reduces reperfusion injury in patients with ST-segment elevation myocardial infarction. Eur Heart J. 2012;33(12):1491-1499.

29. Meier JJ, Gethmann A, Götze O, et al. Glucagon-like peptide 1 abolishes the postprandial rise in triglyceride concentrations and lowers levels of nonesterified fatty acids in humans. Diabetologia. 2006;49(3):452-458.

30. Yerram P, Whaley-Connell A. Novel role for the incretins in blood pressure regulation. Curr Opin Nephrol Hypertens. 2012;21(5):463-468.

31. Nyström T, Gonon AT, Sjöholm A, Pernow J. Glucagon-like peptide-1 relaxes rat conduit arteries via an endothelium-independent mechanism. Regul Pept. 2005;125(1-3):173-177.

32. Carraro-Lacroix LR, Malnic G, Girardi AC. Regulation of $\mathrm{Na}+/$ $\mathrm{H}+$ exchanger NHE3 by glucagon-like peptide 1 receptor agonist exendin-4 in renal proximal tubule cells. Am J Physiol Renal Physiol. 2009;297(6):F1647-F1655.

33. Becker R, Kapitza C, Stechl J, Ruus P, Msihid J. Restitution of glucose disposition with lixisenatide in subjects with type 2 diabetes [Abstract]. Diabetologia. 2012;55 Suppl 1:S335-S336.

34. Distiller L, Ruus P. Pharmacokinetics and pharmacodynamics of GLP-1 agonist AVE0010 in type 2 diabetes patients [Abstract]. Diabetes. 2008;57 Suppl 1:520-P.

35. Meier JJ, Nauck MA, Kranz D, et al. Secretion, degradation, and elimination of glucagon-like peptide 1 and gastric inhibitory polypeptide in patients with chronic renal insufficiency and healthy control subjects. Diabetes. 2004;53(3):654-662.

36. Stechl J, Becker R, Kapitza C, Msihid J. Augmentation of 1st-phase insulin release with lixisenatide in non-diabetic subjects [Abstract]. Diabetologia. 2012;55 Suppl 1:S336.

37. European Medicines Agency. Byetta: EPAR - Product Information. London: European Medicines Agency; 2009 [updated March 25, 2013; cited January 10, 2013]. Available from: http://www.emea.europa. eu/ema/index.jsp?curl=pages/medicines/human/medicines/000698/ human_med_000682.jsp\&mid=WC0b01ac058001d124\#product-info. Accessed April 20, 2013.

38. Liu YH, Ruus P. Pharmacokinetics and safety of the GLP-1 Agonist AVE0010 in patients with renal impairment [Abstract]. Diabetes. 2009;58 Suppl 1:557-P.

39. Liu YH, Ruus P. Effect of the GLP-1 Agonist AVE0010 on absorption of concomitant oral drugs [Abstract]. Diabetes. 2009;58 Suppl 1:495-P.

40. Liu YH, Ruus P, Steinstraesser A, Teichert L. Effect of the GLP-1 agonist lixisenatide on the pharmacokinetics of warfarin [Abstract]. Diabetes. 2010;59 Suppl 1:2128-PO.

41. Thorkildsen C, Neve S, Larsen BD, Meier E, Petersen JS. Glucagon-like peptide 1 receptor agonist ZP10A increases insulin mRNA expression and prevents diabetic progression in $\mathrm{db} / \mathrm{db}$ mice. J Pharmacol Exp Ther. 2003;307(2):490-496.

42. Werner U, Haschke G, Herling AW, Kramer W. Pharmacological profile of lixisenatide: A new GLP-1 receptor agonist for the treatment of type 2 diabetes. Regul Pept. 2010;164(2-3):58-64.

43. Ratner RE, Rosenstock J, Boka G; DR16012 Study Investigators. Dose-dependent effects of the once-daily GLP-1 receptor agonist lixisenatide in patients with Type 2 diabetes inadequately controlled with metformin: a randomized, double-blind, placebo-controlled trial. Diabet Med. 2010;27(9):1024-1032.

44. Meier JJ. GLP-1 receptor agonists for individualized treatment of type 2 diabetes mellitus. Nat Rev Endocrinol. 2012;8(12): $728-742$.
45. Makris K, Spanou L. Is there a relationship between mean blood glucose and glycated hemoglobin? J Diabetes Sci Technol. 2011;5(6): $1572-1583$.

46. Rosenstock J, Forst T, Aronson R, et al. Once-daily lixisenatide added on to consistently titrated insulin glargine plus oral agents in type 2 diabetes: the getgoal-duo 1 study [Abstract]. Diabetologia. 2012;55 Suppl 1:S333.

47. Aronson R, Riddle M, Home P, et al. Efficacy and safety of once-daily lixisenatide in type 2 diabetes insufficiently controlled with basal insulin \pm metformin: GetGoal-L study [Abstract]. Diabetologia. 2012; 55 Suppl 1:S8.

48. Seino Y, Min KW, Niemoeller E, Takami A; EFC10887 GETGOAL-L Asia Study Investigators. Randomized, double-blind, placebo-controlled trial of the once-daily GLP-1 receptor agonist lixisenatide in Asian patients with type 2 diabetes insufficiently controlled on basal insulin with or without a sulfonylurea (GetGoal-L-Asia). Diabetes Obes Metab. 2012;14(10):910-917.

49. Rosenstock J, Raccah D, Korányi L, et al. Efficacy and safety of lixisenatide once-daily versus exenatide twice-daily in patients with type 2 diabetes insufficiently controlled on metformin (GetGoal-X) [Abstract]. Diabetologia. 2011;54 Suppl 1:S317-S318

50. Kapitza C, Forst T, Coester HV, Poitiers F, Ruus P, Hincelin-Méry A. Pharmacodynamic characteristics of lixisenatide once daily versus liraglutide once daily in patients with type 2 diabetes insufficiently controlled on metformin. Diabetes Obes Metab. 2013. Epub January $31,2013$.

51. Ahrén B, Leguizamo Dimas A, Miossec P, Saubadu S, Aronson R. Efficacy and safety of lixisenatide once-daily morning or evening injections in type 2 diabetes inadequately controlled on metformin (GetGoal-M). Diabetes Care. Epub March 27, 2013.

52. Raccah D, Miossec P, Esposito V, Niemoeller E, Cho M, Gerich J. Efficacy and safety of lixisenatide in elderly ( $\geq 65$ years) and very elderly ( $\geq 75$ years) patients with type 2 diabetes: an analysis from the GetGoal phase 3 program [Poster]. 48th EASD Annual Meeting 1-5 October 2012. P815.

53. Fonseca VA, Alvarado-Ruiz R, Raccah D, Boka G, Miossec P, Gerich JE; EFC6018 GetGoal-Mono Study Investigators. Efficacy and safety of the once-daily GLP-1 receptor agonist lixisenatide in monotherapy: a randomized, double-blind, placebo-controlled trial in patients with type 2 diabetes (GetGoal-Mono). Diabetes Care. 2012;35(6): 1225-1231.

54. Lorenz M, Pfeiffer C, Steinstraesser A, Ruus P, Becker R. Effects of lixisenatide once daily on gastric emptying and its relationship to postprandial glycemia in type 2 diabetes mellitus. Diabetes. 2012, 61:A212-A344. [Abstract 1085-P].

55. Bolli G, Munteanu M, Dotsenko S, Niemoeller E, Boka G, Hanefeld M. Efficacy and safety of lixisenatide once-daily versus placebo in patients with type 2 diabetes mellitus insufficiently controlled on metformin (GetGoal-F1) [Abstract]. Diabetologia. 2011;54 Suppl 1: S316-S317.

56. Ratner RE, Hanefeld M, Shamanna P, et al. Post-meal pharmacodynamic profile of lixisenatide once daily vs placebo in T2DM insufficiently controlled on SU \pm metformin (GetGoal-S) [Abstract D-0743]. Proceedings of the World Diabetes Congress 2011; December 4-8, 2011; Dubai, United Arab Emirates.

57. Horowitz M, Rayner CK, Jones KL. Mechanisms and clinical efficacy of lixisenatide for the management of type 2 diabetes. Adv Ther. 2013;30(2):81-101.

58. Bolli G, Munteanu M, Dotsenko S, Niemoeller E, Wardęcki M, Hanefeld M. Long-term (up to 2 Years) safety of lixisenatide once daily vs placebo in $\mathrm{t} 2 \mathrm{dm}$ insufficiently controlled on metformin (GetGoal-F1) [Abstract O-0595]. Proceedings of the World Diabetes Congress 2011; December 4-8, 2011; Dubai, United Arab Emirates.

59. Pinget M, Goldenberg R, Niemoeller E, Muehlen-Bartmer I, Aronson R. Efficacy and safety of lixisenatide once daily versus placebo in patients with type 2 diabetes insufficiently controlled on pioglitazone (GetGoal-P) [Abstract]. Diabetologia. 2012;55 Suppl 1:S334. 
60. De Heer J, Holst JJ. Sulfonylurea compounds uncouple the glucose dependence of the insulinotropic effect of glucagon-like peptide 1 . Diabetes. 2007;56(2):438-443.

61. European Medicines Agency. Byetta: EPAR - Scientific Discussion. London: European Medicines Agency; 2006. Available from: http:// www.emea.europa.eu/ema/index.jsp?curl=pages $/$ medicines $/$ human $/$ medicines/000698/human_med_000682.jsp\&mid=WC0b01ac058001d124 Accessed April 20, 2013.

62. De La Loge C, Trudeau E, Marquis P, et al. Responsiveness and interpretation of a quality of life questionnaire specific to upper gastrointestinal disorders. Clin Gastroenterol Hepatol. 2004;2(9):778-786.

63. Russell S. Incretin-based therapies for type 2 diabetes mellitus: a review of direct comparisons of efficacy, safety and patient satisfaction. Int $J$ Clin Pharm. 2013;35(2):159-172.
64. Madsbad S. Exenatide and liraglutide: different approaches to develop GLP-1 receptor agonists (incretin mimetics) - preclinical and clinical results. Best Pract Res Clin Endocrinol Metab. 2009;23(4): 463-477.

65. Aroda VR, Henry RR, Han J, et al. Efficacy of GLP-1 receptor agonists and DPP-4 inhibitors: meta-analysis and systematic review. Clin Ther. 2012;34(6):1247-1258.

66. Peter R, Okoseime OE, Rees A, Owens DR. Postprandial glucose a potential therapeutic target to reduce cardiovascular mortality. Curr Vasc Pharmacol. 2009;7(1):68-74.

\section{Publish your work in this journal}

Diabetes, Metabolic Syndrome and Obesity: Targets and Therapy is an international, peer-reviewed open-access journal committed to the rapid publication of the latest laboratory and clinical findings in the fields of diabetes, metabolic syndrome and obesity research. Original research, review, case reports, hypothesis formation, expert opinion and commentaries are all considered for publication. The manuscript management system is completely online and includes a very quick and fair peer-review system, which is all easy to use. Visit http://www.dovepress.com/testimonials.php to read real quotes from published authors.

Submit your manuscript here: http://www.dovepress.com/diabetes-metabolic-syndrome-and-obesity-targets-and-therapy-journal 